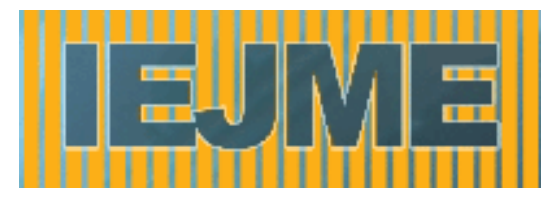

International Electronic Journal of

\title{
Mathematics Education
}

\section{ADDRESSING THE PRINCIPLES FOR SCHOOL MATHEMATICS: A CASE STUDY \\ OF ELEMENTARY TEACHERS' PEDAGOGY AND PRACTICES IN AN URBAN \\ HIGH-POVERTY SCHOOL}

Robert Q. Berry

\author{
Linda Bol
}

Sueanne E. McKinney

\begin{abstract}
The extent to which four novice teachers assigned to an urban high-poverty school implemented the Principles of School Mathematics during their mathematics instruction program was investigated using a case study design. The research team conducted 36 unannounced observations of the participating teachers and utilized a developed assessment to guide their observations. Results indicated that only one teacher was judged proficient for all the Principles. The remaining three teachers fell short in the implementation and direction of the Principles. Detailed descriptions of the pedagogical practices of the teachers are provided.
\end{abstract}

KEYWORDS. Mathematics, Urban Schools, Pedagogy.

\section{INTRODUCTION}

Imagine a classroom, a school, or a school district where all students have access to high-quality, engaging mathematics instruction. There are ambitious expectations for all, with accommodations for those who need it. Knowledgeable teachers have adequate resources to support their work, and are continually growing as professional. . . (National Council of Teachers of Mathematics, 2000, p. 3).

The above statement highlights the new vision of a high-quality mathematics learning environment for students in grades pre-kindergarten through twelve set forth by the National Council of Teachers of Mathematics (NCTM), a professional organization committed to 
excellence in the teaching and learning of mathematics. Their milestone document, Principles and Standards for School Mathematics (PSSM) (2000) offers a framework for providing a rigorous mathematics education program in order to improve the mathematics literacy and success of diverse student populations. This document outlines six principles (Equity, Curriculum, Teaching, Learning, Assessment and Technology) that describe specific and crucial elements that influence mathematics educational programs. According to the NCTM:

“. . the power of these Principles as guides and tools for decision making derives from their interaction in the thinking of educators. The Principles will come fully alive as they are used together to develop a high-quality school mathematics program" (NCTM, 2000, p. 12).

Although PSSM (NCTM, 2000) outline explicit targets for the teaching and learning of mathematics, many elementary classrooms continue to fall short in actualizing these goals (Berry, 2003; Palacios, 2005). Of particular concern for educators and the mathematics community is the underperformance of urban students and the disparities among the subgroups. Recognizing that major factors such as high teacher attrition levels, the difficulty in attracting highly-qualified mathematics educators, and the perils of living in high-poverty and depressed areas play a significant role in achievement levels, the National Assessment of Educational Progress (NAEP) data implies that urban students are not meeting academic success because they are not experiencing instructional practices consistent with the recommendations suggested by the NCTM (Berry, 2003; Lubienski, 2001). When teachers of mathematics' methodology and instructional practices are consistent with each of the NCTM Principles, students are more apt to develop a rich and conceptual understanding of the different mathematical ideas and processes, as well as skill and procedural fluency (Hiebert, 2003; Merlino \& Wolff; NCTM, 2000; Spillane \& Zeuli, 1999; Turner, 1999). For example, a recent investigation by McKinney, Bol, and Berube (2008) investigated the mathematics instructional practices of Star Teachers, or those teachers that have proven effective with urban populations. A term endeared by Haberman $(2006,1995)$, star teachers. . . "are outstandingly successful: their students score higher on standardized tests; parents and children think they are great; principals rate them highly; other teachers regard them as outstanding; cooperative universities regard them as superior; and they evaluate themselves as outstanding teacher" (Haberman, 1995, p. 1). The research team concluded that star teachers demonstrated those instructional practices that are aligned with NCTM's Principles (2008). McKinney, Berry, and Robinson (2008) also investigated the mathematics instructional practices of star teachers and compared them to the practices of teachers not so identified. They reported 
that star teachers demonstrated instructional practices supported by the NCTM Principles more frequently than non-stars. According to Sillane and Zeuli (1999), when teachers' instructional practices are aligned with NCTM's standards, students tend to meet greater success on mathematics assessments. Therefore, it is plausible to assume that if teachers embrace the NCTM Principles with finesse and incorporate them within their instructional program and practices, student's mathematical achievement would increase. The research question that guided this study was:

1. To what extent are the Principles of School Mathematics addressed through the mathematics instructional practices and pedagogy of four selected urban high-poverty school elementary teachers?

Findings from this investigation will contribute to the knowledge base as to what mathematics teachers actually do to impact student learning and understanding of important mathematical ideas and concepts (U.S. Department of Education, 2008). Additionally, data from this study may also assist teachers in executing NCTM's Principles in their mathematics classroom.

\section{Conceptual Framework}

The literature review concentrates on those areas related to mathematics education in urban high-poverty schools: (a) The Plight of Urban Students' Mathematics Experiences and (b) Elementary Teacher Preparation and Instructional Pedagogy.

\section{The Plight of Urban Students' Mathematics Experiences}

The only ongoing assessment of mathematics achievement in the United States is the National Assessment of Educational Progress (NAEP) which gauges student mathematics achievement in grades 4, 8 and 12 (Rampey, Lutkus \& Dion, 2006). This assessment instrument provides information on what students know, understand and can do mathematically. The Trial Urban District Assessment (TUDA), a distinctive project of NAEP, began assessing the mathematical performance of $4^{\text {th }}, 8^{\text {th }}$ and $12^{\text {th }}$ grade students from eleven large urban metropolitan school districts (Atlanta, Austin, Boston, Charlotte, Chicago, Cleveland, Houston, Los Angeles, New York, San Diego and Washington, DC) both in 2003 and 2005. This data has been used to show that several factors such as socioeconomic status, school policies, and allocation of human and material resources, and instructional practices may account for performance disparities (Oakes,1990; Secada, 1992; Strutchens \& Silver, 2000; Tate, 1997). 
Students' achievement on the NAEP mathematics assessment is reported as Below Basic, Basic, Proficient and Advanced. For example, fourth-graders performing at the Basic level should be able to estimate and use basic facts to perform simple computations with whole numbers and show some understanding of fractions and decimals (Rampey, Lutkus, \& Dion, 2006). Those at the Proficient level should be able to use whole numbers to estimate, compute and determine if specific results are reasonable. Students from this grade band should also have a conceptual understanding of fractions and decimals and should be able to solve real-world problems. Fourthgraders performing at the Advanced level should be able to solve complex and non-routine realworld problems. These students are expected to draw logical conclusions and justify answers and solution processes (Rampey, Lutkus \& Dion, 2006). With the exception of Austin and Charlotte, average scores for the participating districts were lower than the national average in 2005 . Charlotte was the only participating urban district to report higher scores in 2003; all others were below the national average. The mathematics achievement of fourth grade students from the eleven participating urban school districts for 2003 and 2005 are presented in Table 1.

Table 1. Percentage of Students by Mathematics Achievement Level for Grade 4 in Urban Districts for 2003 and 2005

\begin{tabular}{|c|c|c|c|c|c|c|c|c|}
\hline \multicolumn{9}{|c|}{ Mathematics Achievement Levels } \\
\hline \multirow[b]{3}{*}{ Districts } & \multicolumn{2}{|c|}{ Below Basic } & \multirow{2}{*}{\multicolumn{2}{|c|}{$\begin{array}{c}\text { At or above } \\
\text { Basic }\end{array}$}} & \multirow{2}{*}{\multicolumn{2}{|c|}{$\begin{array}{c}\text { At or above } \\
\text { Proficient }\end{array}$}} & \multicolumn{2}{|c|}{ At Advanced } \\
\hline & & & & & & & & \\
\hline & 2003 & 2005 & 2003 & 2005 & 2003 & 2005 & 2003 & 2005 \\
\hline Nation & $24 *$ & 21 & $76^{*}$ & 79 & 31 & 35 & $4 *$ & 5 \\
\hline Atlanta & $50 *$ & 43 & $50 *$ & 57 & 13 & 17 & 2 & 3 \\
\hline Austin & - & 15 & - & 85 & - & 40 & - & 7 \\
\hline Boston & $41 *$ & 28 & $59 *$ & 72 & $12 *$ & 22 & 1 & 2 \\
\hline Charlotte & 16 & 14 & 84 & 86 & 41 & 44 & $6^{*}$ & 9 \\
\hline Chicago & 50 & 48 & 50 & 52 & 10 & 13 & 1 & 1 \\
\hline Cleveland & $49^{*}$ & 40 & $51^{*}$ & 60 & 10 & 13 & 0 & 0 \\
\hline $\mathrm{DC}$ & $64^{*}$ & 55 & $36^{*}$ & 45 & $7 *$ & 10 & 1 & 1 \\
\hline Houston & $30 *$ & 23 & $70 *$ & 77 & $18^{*}$ & 26 & 1 & 3 \\
\hline Los Angeles & $48^{*}$ & 42 & $52^{*}$ & 58 & $13^{*}$ & 18 & 1 & 2 \\
\hline New York & $33^{*}$ & 27 & $67^{*}$ & 73 & $21^{*}$ & 26 & 2 & 3 \\
\hline San Diego & $34 *$ & 26 & $66^{*}$ & 74 & $20 *$ & 29 & $2^{*}$ & 4 \\
\hline
\end{tabular}

* Significantly different from 2005

— Not available. The district did not participate in 2003 Table.

While the urban school districts are showing positive increases in mathematics achievement, researchers, school administrators and mathematics education faculties are becoming increasingly apprehensive about the mathematics achievement levels of urban students and the disparities that exist among different subgroups of students. As stated earlier, these concerns may be indicative of the instruction that these students receive (Lubienski, 2001). 
The literature makes clear that teachers' pedagogical decisions and activities make a difference in students' mathematics achievement and that students' understanding of mathematics is shaped by the teaching they encounter in school (Berry, 2003; Darling-Hammond, 2000; Merlino \& Wolff, 2001; NCTM, 2000; Spillane \& Zeuli, 1999; Turner, 1999). For example, Wenglinsky (2002) examined how mathematics achievement levels of more than 7,000 students on the 1996 NAEP mathematics assessment were related to measures of teaching quality. He found that student mathematics achievement was influenced by both teacher content background and teacher education or professional development coursework, particularly in how to work with diverse student populations. Wenglinsky (2002) further stated, "Regardless of the level of preparation students bring into the classroom, decisions that teachers make about classroom practices can either greatly facilitate student learning or serve as an obstacle to it" (p. 7). Sanders and Rivers (1996) also investigated teacher quality and mathematics achievement. They found that significant gains in mathematics achievement levels were made by students when placed with an effective teacher over a three year span. Therefore, in order to impact the mathematics achievement of urban populations, teachers must have a thorough understanding of the best practices for reaching diverse populations as articulated by the NCTM (2000).

\section{Elementary Teacher Preparation and Pedagogy}

The mathematics education of elementary school students has received increased attention because many elementary students lack preparation for rigorous mathematics in the upper grades. Elementary school teachers receive training in all the core subjects (mathematics, science, reading, and social studies). Consequently, they may lack the necessary depth and understanding in mathematics content and pedagogy to prepare elementary students for rigorous mathematics in middle and high school. Shifts in the elementary mathematics curriculum have led to a substantial increase in the content knowledge needed to teach elementary mathematics (Hill, Rowan, \& Ball, 2005). Elementary teachers need not only to be able to teach arithmetic, but they must also be able to teach geometry, algebraic concepts, measurement, and data analysis and probability. In addition, they must be able to teach problem solving skills, represent mathematical concepts in multiple ways, connect mathematical concepts within mathematics and to other subject areas, and be able to analyze students' thinking about mathematics (Hill, Rowan, \& Ball, 2005). Reys and Fennell (2003) found that many pre-service elementary teachers were uncomfortable with thinking of themselves as mathematics teachers even though they would be the primary persons who would organize and deliver mathematics instruction for elementary 
school students. One could readily assume that these pre-service teachers may be uncomfortable because they do not understand the mathematics content well, do not know how students learn mathematics, or are unable to use appropriate instruction and assessment strategies to help students learn mathematics with understanding (Hill, Rowan, \& Ball, 2005; Hill, Schillings, \& Ball, 2004). Likewise, researchers are concerned about in-service elementary teachers' mathematics content knowledge (Kilpatrick, Swafford, \& Findell, 2001) and their use of mathematics pedagogical content knowledge to provide effective learning opportunities for students (Hill, Schillings, \& Ball, 2004).

The concerns surrounding pedagogy has led researchers to look at different forms of teaching methodology as related to mathematics instruction. The two dominate methodologies include traditional practices and alternative practices. A traditional methodology focuses on teaching mathematical procedures with little, if any, emphasis on conceptual understandings (Fitzgerald \& Bouck, 1993; Hiebert, 2003; Lubienski, 2001; Strutchens \& Silver, 2000; Tharp \& Gallimore, 1988). Typical mathematics classrooms are oriented around abstract algorithms where students work a multiple of problems to demonstrate procedural knowledge (Bransford, Brown \& Cocking, 1999; NCTM, 2000; Watson, 2006). Drill and practice is key. Although new directions for mathematics instruction are advocated by the NCTM (2000) traditional mathematics pedagogy continues to dominate classrooms across the United States, even though they aren't supportive of the NCTM's six principles (Hiebert, 2003; NCTM, 2000; Van De Walle, 2006). Although not explicit to mathematics teaching, Haberman $(2005,1995,1991)$ used the descriptor "pedagogy of poverty" to define traditional, ritualistic routines which are often practiced in urban classrooms and can be readily seen in the traditional mathematics classroom. For example, when mathematics teachers simply "give out" information, assign problems, monitor seatwork, and/or assign homework, they are supporting the "pedagogy of poverty" as defined by Haberman (2005, 1991). Stinson (2006) and Strutchens (2000) contended that the "pedagogy of poverty" is typically faced by urban high-poverty students throughout their mathematics education, and are significant factors contributing to their poor mathematics achievement.

In contrast to traditional mathematics pedagogy, alternative approaches emphasize participatory and inquiry driven practices that highlight reasoning and problem solving skills and student discourse. Alternative approaches are more hands-on and student centered, allowing the teacher to facilitate students' mathematical learning. There is documented evidence that suggests that alternative approaches allow students to develop a conceptual understanding of the different mathematical ideas (Hiebert, 1986; Hiebert \& Carpenter, 1992; NCTM, 1989, 1991, 1995, 2000; 
Owens, 1993; Wenglinsky, 2002). Further, students tend to perform better on mathematics achievement tests when teachers provide inquiry driven and hands-on learning opportunities (Wenglinsky, 2002).

Alternative approaches to teaching mathematics are also in concert with the NCTM Principles and with what Haberman $(2005,1991)$ defines as "good teaching" for urban highpoverty students. For example, when students are actively involved and encouraged to see major concepts and big ideas, they are being presented with teaching practices proven to be effective and especially successful for working with urban populations. Table 2 provides a cross comparison between each of the NCTM's six Principles and Haberman's Acts of Good Teaching.

Table 2. A Cross Comparison of the NCTM's Six Principles and Haberman's Acts of Good Teaching

NCTM's Principles for School Mathematics * Haberman's Acts of Good Teaching

EQUITY: Excellence in mathematics education Students are involved with issues they regard as vital requires equity - high expectations and strong concerns.

support for all students.

Students are involved with applying ideals such as fairness, equity, or justice to their world.

CURRICULUM: A curriculum is more than a Students are being helped to see major concepts, big collection of activities: it must be coherent, ideas, and general principles and are not merely engaged focused on important mathematics, and well in the pursuit of isolated facts.

articulated across the grades.

TEACHING: Effective mathematics teaching Students are asked to think about an idea in a way that requires understanding what students know and questions common sense or a widely accepted assumption need to learn and then challenging and supporting that relates new ideas to ones learned previously, or that them to learn it well.

applies an idea to the problems of living.

Students are actively involved.

Students are directly involved in a real-life experience.

Students are actively involved in heterogeneous groups.

Students are being helped to see major concepts, big ideas, and general principles and are not merely engaged in the pursuit of isolated facts.

LEARNING: Students must learn mathematics Students are being helped to see major concepts, big ideas, with understanding, actively building new and general principles and are not merely engaged in the knowledge from experience and prior knowledge. pursuit of isolated facts.

Students are involved in planning what they will be doing.

Students are involved in redoing, polishing, or perfecting their work.

Students are involved in planning what they will be doing.

ASSESSMENT: Assessment should support the Students are involved in reflecting on their own lives and learning of important mathematics and furnish how they have come to believe and feel as they do.

useful information to both teachers and students. Students are involved with explanations of human differences.

TECHNOLOGY:_Technology is essential in Teachers involve students with the technology of teaching and learning mathematics; it influences information access.

the mathematics that is taught and enhances

students' learning.

* (NCTM, 2000, p. 11). 


\section{Methodology}

This investigation was conducted in one low-performing school within a large southeastern metropolitan city. The district contains approximately 130,000 students, with over 60,000 elementary school students (kindergarten through fifth grades).

A case study methodology was utilized because the fundamental case in question involved four elementary teachers who teach in one of the district's high poverty schools which had not met the state's benchmark score on the standardized mathematics assessment. The student demographics for Monarch Elementary School (pseudonym) include 0.7\% Native Americans, 3.8\%, Multi-Racial students, 1.7\% Asians, 62.1\% African Americans, 26.4\% Hispanics, and 5.2\% White. Nearly $68 \%$ of the students at Monarch Elementary School qualified for free or reducedprice school lunches. Olson and Jerald (1998) define a high-poverty school in which at least 50\% of the students qualified for free or reduced-price lunches; this definition was utilized for the purpose of this study.

Criterion selection was employed for this study. That is, teachers with the majority of their students not meeting the state's benchmark score in mathematics were selected as participants for this study. The four female teachers-Angela, Betty, Carol, and Diane (pseudonyms) - were between the ages of 26-32 years $($ mean $=29)$ with each only having one year of teaching experience in a high-poverty school. In regards to race, Angela, Betty and Carol are Caucasian, and Diane is African American. They graduated from the same state university after completing a traditional teacher preparation program. Additionally, all are endorsed in elementary education and have state appropriate certification.

\section{Teacher Performance Assessment and Procedures}

An observation instrument was developed based on the Principles from PSSM (2000), and the participating school division's Teacher Performance Assessment instrument. The Teacher Performance Assessment instrument consisted of research based descriptors of essential qualities of effective pedagogy and methodology for teaching. Specifically, the research team categorized 40 descriptors from the Teacher Performance Assessment instrument into the six Principles outlined in the NCTM's PSSM (see Table 5). Although the Teacher Performance Assessment contained a total number of 64 items, some of these items did not align with any of the Principles, and were not included in the observation instrument. Because the researchers relied on the assessment instrument already employed in the division, there were more items for some scales 
compared to others. The blueprint provides an overview of the Principles or scales and the number of items by scale (see Table 3 ).

Table 3. Blueprint of Observation Instrument

\begin{tabular}{|c|c|c|c|}
\hline Principle/ Scale & Description of Principle & \# Items & Sample Item \\
\hline Equity & $\begin{array}{l}\text { Teachers are responsive to various } \\
\text { learning preferences and allocate their } \\
\text { time and resources equitably to help } \\
\text { students attain and perhaps exceed the } \\
\text { mathematics goals for their grade level. }\end{array}$ & 8 & $\begin{array}{l}\text { Asks higher level questions to } \\
\text { all learners. }\end{array}$ \\
\hline Curriculum & $\begin{array}{l}\text { Teachers understand the big ideas of } \\
\text { mathematics and are able to see how } \\
\text { these ideas connect across the grade } \\
\text { bands. }\end{array}$ & 3 & $\begin{array}{l}\text { Demonstrates knowledge of } \\
\text { state mandated standards. }\end{array}$ \\
\hline Teaching & $\begin{array}{l}\text { Teachers recognize that there is no one } \\
\text { right way to teach and that using } \\
\text { various pedagogical styles are } \\
\text { necessary to engage students } \\
\text { mathematically. }\end{array}$ & 12 & $\begin{array}{l}\text { Draws on extensive repertoire } \\
\text { of instructional skills. }\end{array}$ \\
\hline Learning & $\begin{array}{l}\text { Teachers help students learn } \\
\text { mathematics not as isolated facts and } \\
\text { procedures but how mathematics } \\
\text { concepts are interconnected and } \\
\text { connected to other subject areas. }\end{array}$ & 10 & $\begin{array}{l}\text { Connects new learning to real } \\
\text { world experiences. }\end{array}$ \\
\hline Assessment & $\begin{array}{l}\text { Teachers utilize multiple forms of } \\
\text { assessments and ask students to reflect } \\
\text { on their thinking. }\end{array}$ & 5 & $\begin{array}{l}\text { Uses multiple assessment } \\
\text { strategies. }\end{array}$ \\
\hline Technology & $\begin{array}{l}\text { Teachers incorporate technology and } \\
\text { mathematics instruction as to impact } \\
\text { student achievement. }\end{array}$ & 2 & $\begin{array}{l}\text { Appropriate } \\
\text { technology. }\end{array}$ \\
\hline
\end{tabular}

Eight indicators were categorized under the Equity Principle. These eight indicators primarily focus on meeting the variety of instructional needs of students in the mathematics classroom. Three indicators were categorized under the Curriculum Principle; these indicators focus on knowledge and use of standards, curriculum, and content. Twelve indicators categorized under the Teaching Principle focus primarily on teachers' use of instructional materials and instructional strategies. Ten indicators categorized under the Learning Principle focuses primarily on how students experience their learning. The five indicators under the Assessment Principle focus on how assessments are used to guide the instruction. The two indicators under Technology Principle focus on the selection and use of technology.

Steps were taken to enhance the reliability and validity of the observation measure. Validation of the instrument was addressed in peer-debriefing sessions as a regular part of the 
research process (Creswell, 1998; Lincoln \& Guba, 1985). After independently reviewing the teacher assessment measure, the research team along with another university faculty member worked collaboratively to further review the categories and items on the evaluation observation protocol. The research team consisted of an assistant principal, a lead mathematics teacher, and a university mathematics methods faculty. In addition, further expert review served to validate the instrument. The categorized evaluation observation protocol was examined by two university mathematics education faculty members (not on the research team), as well as the school district's mathematics Instructional Coordinator. The participating parties agreed that the teacher essential indicators outlined in the proposed evaluation tool were representative of the NCTM's Principles. Inter-observer reliability was established by having the research team observe 19 classrooms within the participating school, with teachers who were non-participants in this study and with different grade levels. To address the consistency across observers the percentage of agreement for each item was calculated. A conservative estimate of consistency was employed because agreement was designated only when all three observers concurred that the instruction reflected the descriptor or item. For example, the research team agreed 14 of the 19 times on whether instruction demonstrated high teacher expectation of student achievement as indicative of the Equity Principle. Across all items and scales (Principles), the percentage of agreement was .76, indicating good inter-observer reliability. By scale, the averages were .71 for Equity, .86 for Curriculum, .71 for Teaching, .67 for Learning, .72 for Assessment, and .87 for Technology.

After addressing the reliability and validity of the observation instrument, the research team conducted the classroom observations over a period of seven months. The four teachers were observed nine times, with each researcher observing each teacher three times during their mathematics instruction. Typically, the mathematics time block was 55 minutes in duration. All observations were conducted by individual researchers and were unannounced. The researchers adopted the role of non-participant observers who strived to remain detached from the teacher and any classroom interactions (Gall, Borg \& Gall, 1996), and recorded whether or not the teachers demonstrated a particular behavior that comprised the items or descriptors on the observation instrument.

\section{Data Analysis and Findings}

Summary data for each teacher by Principle is provided in Table 4. This table shows how many of the indicators for each Principle the teachers met, and whether they were judged to be 
proficient on each Principle assessed. In order to be deemed proficient for an indicator or item under each Principle, the research team agreed that the teacher must demonstrate the behavior in two out of three observations conducted by individual observers, and also two out of the three observers must have deemed the teacher proficient. For example, Betty was deemed proficient for "support critical discourse among learners" because Observers 1 and 2 both observed this in at least two out of three of their individual observations. Overall, the researchers predetermined that a teacher would be judged as proficient on a Principle when proficiency was demonstrated on the majority of the descriptors or items categorized under the Principle. More specifically, this meant that teachers needed to be proficient on 6 of the 8 items for Equity, 2 of 3 for Curriculum, 10 of 12 for Teaching, 8 of 10 for Learning, 4 of 5 for Assessment, and 2 of 2 for technology.

Table 4._Proficiency for Each Principle Demonstrated by Individual Teachers

\begin{tabular}{lcccccc}
\hline Teachers & Equity & Curriculum & Teaching & Learning & Assessment & Technology \\
Angela & 5 of 8 & 2 of $3^{*}$ & 5 of 12 & 4 of 10 & 3 of 5 & 0 of 2 \\
Betty & 6 of $8^{*}$ & 3 of $3^{*}$ & 5 of 12 & 3 of 10 & 3 of 5 & 2 of $2^{*}$ \\
Carol & 5 of 8 & 3 of $3^{*}$ & 8 of 12 & 6 of 10 & 1 of 5 & 0 of 2 \\
Diane & 7 of $8^{*}$ & 3 of $3^{*}$ & 10 of $12^{*}$ & 10 of $10^{*}$ & 4 of $5 *$ & 2 of $2^{*}$ \\
\hline
\end{tabular}

* indicates proficiency

The overall results presented in Table 4 revealed a good deal of variation in results by individual teacher. Looking at each of the Principles as a whole, all teachers were judged to be proficient for the Curriculum Principle. However, teacher proficiency for each of the remaining six principles varied. Two teachers, Betty and Diane did meet proficiency for the Equity Principle, while the other two teachers, Angela and Carol, did not. Only one teacher, Diane, was judged proficient for the Teaching, Learning and Assessment Principles. Finally, two teachers, Betty and Diane met proficiency for the Technology Principle.

Although the summary data provided valuable information across teachers, examining the results by individual teacher illuminates the specific teaching practices that exemplify the presence or absence of indicators associated with the Principles. Table 5 shows the proficiency designations for individual teachers on each of the items categorized under a Principle. In order to provide detailed descriptions for individual teachers' pedagogy and teaching behaviours in a concise manner, the data is organized according to each of the seven Principles. 
Table 5. Summary of Teacher's Proficiency using the Observation Protocol

\begin{tabular}{|c|c|c|c|c|}
\hline Teacher Practice/Indicator & $\begin{array}{l}\text { Teacher A } \\
\text { Angela }\end{array}$ & $\begin{array}{l}\text { Teacher B } \\
\text { Betty }\end{array}$ & $\begin{array}{l}\text { Teacher C } \\
\text { Carol }\end{array}$ & $\begin{array}{l}\text { Teacher D } \\
\text { Diane }\end{array}$ \\
\hline \multicolumn{5}{|l|}{ Equity } \\
\hline $\begin{array}{l}\text { 1. Demonstrates TESA (teacher expectations - student achievement) } \\
\text { Behaviors. }\end{array}$ & $\mathrm{X}$ & $\mathrm{X}$ & $\mathrm{X}$ & $\mathrm{X}$ \\
\hline 2. Invites learner questions/comments. & $\mathrm{X}$ & $\mathrm{X}$ & $\mathrm{X}$ & $\mathrm{X}$ \\
\hline 3. Asks higher level questions to all learners. & & $\mathrm{X}$ & $\mathrm{X}$ & $\mathrm{X}$ \\
\hline 4. Provides adequate "think time." & $\mathrm{X}$ & $\mathrm{X}$ & $\mathrm{X}$ & $\mathrm{X}$ \\
\hline $\begin{array}{l}\text { 5. Differentiates instruction; Provides individual/small group instruction } \\
\text { when needed. }\end{array}$ & & & & $\mathrm{X}$ \\
\hline 6. Utilizes resources during instruction to address ability levels. & $\mathrm{X}$ & & & $\mathrm{X}$ \\
\hline 7. Utilizes effective reinforcement techniques. & $\mathrm{X}$ & $\mathrm{X}$ & $\mathrm{X}$ & $\mathrm{X}$ \\
\hline 8. Supports critical discourse among learners. & & $\mathrm{X}$ & & \\
\hline Curriculum & $\mathrm{X}$ & $\mathrm{X}$ & $\mathrm{X}$ & $\mathrm{X}$ \\
\hline 1. Demonstrates knowledge of state mandated standards. & & & & \\
\hline 2. Follows mandated state curriculum, and adds personal creativity. & & $\mathrm{X}$ & $\mathrm{X}$ & $\mathrm{X}$ \\
\hline 3. Demonstrates content knowledge. & $\mathrm{X}$ & $\mathrm{X}$ & $\mathrm{X}$ & $\mathrm{X}$ \\
\hline \multicolumn{5}{|l|}{ Teaching } \\
\hline 1. Projects enthusiasm for the material. & $\mathrm{X}$ & $\mathrm{X}$ & $\mathrm{X}$ & $\mathrm{X}$ \\
\hline 2. Appropriate selection and use of materials. & $\mathrm{X}$ & $\mathrm{X}$ & $\mathrm{X}$ & \\
\hline 3. Content is well structured, sequenced, and presented in a coherent manner. & $\mathrm{X}$ & $\mathrm{X}$ & $\mathrm{X}$ & $\mathrm{X}$ \\
\hline $\begin{array}{l}\text { 4. Learning activities selected are diverse and enhance student understanding } \\
\text { of content material. }\end{array}$ & & $\mathrm{X}$ & $\mathrm{X}$ & $\mathrm{X}$ \\
\hline 5. Instructional groups are utilized and are productive. & & & & $\mathrm{X}$ \\
\hline 6. Draws on an extensive repertoire of instructional skills. & & & & $\mathrm{X}$ \\
\hline 7. Problem-based learning and reasoning is emphasized. & & & $\mathrm{X}$ & $\mathrm{X}$ \\
\hline 8. Instruction is modality based. & $\mathrm{X}$ & & & $\mathrm{X}$ \\
\hline 9. Connects lesson with other disciplines. & & $\mathrm{X}$ & $\mathrm{X}$ & $\mathrm{X}$ \\
\hline 10. Activities require student thinking. & $\mathrm{X}$ & & $\mathrm{X}$ & $\mathrm{X}$ \\
\hline 11. Utilizes manipulatives. & & & & $\mathrm{X}$ \\
\hline 12. Incorporates the Process Standards during instruction. & & & $\mathrm{X}$ & $\mathrm{X}$ \\
\hline \multicolumn{5}{|l|}{ Learning } \\
\hline 1. Checks for student understanding throughout lesson. & $\mathrm{X}$ & $\mathrm{X}$ & $\mathrm{X}$ & $\mathrm{X}$ \\
\hline 2. Learning with understanding is emphasized. & & & $\mathrm{X}$ & $\mathrm{X}$ \\
\hline 3. Connects new learning to prior learning. & & & & $\mathrm{X}$ \\
\hline 4. Connects new learning to real world experiences. & $\mathrm{X}$ & $\mathrm{X}$ & $\mathrm{X}$ & $\mathrm{X}$ \\
\hline $\begin{array}{l}\text { 5. Adjustments are made to encourage student engagement, and to assist } \\
\text { students in overcoming common error patterns. }\end{array}$ & $\mathrm{X}$ & & & $\mathrm{X}$ \\
\hline 6. Students actively participate in the learning process. & & $\mathrm{X}$ & $\mathrm{X}$ & $\mathrm{X}$ \\
\hline 7. All students are on task. & & & $\mathrm{X}$ & $\mathrm{X}$ \\
\hline 8. Emphasizes retention and transfer of new learning. & & & & $\mathrm{X}$ \\
\hline 9. Activities and/or assignments enhance student learning. & $\mathrm{X}$ & & $\mathrm{X}$ & $\mathrm{X}$ \\
\hline 10. Opportunities for student reflection are provided. & & & & $\mathrm{X}$ \\
\hline \multicolumn{5}{|l|}{ Assessment } \\
\hline $\begin{array}{l}\text { 1. Informal assessments are utilized (e.g. observations, conferences, and } \\
\text { interviews) to make adjustments with instructional practices and student } \\
\text { learning. }\end{array}$ & $\mathrm{X}$ & $\mathrm{X}$ & & $\mathrm{X}$ \\
\hline $\begin{array}{l}\text { 2. Formal assessments are utilized to make adjustments with instructional } \\
\text { practices and student learning. }\end{array}$ & & & & $\mathrm{X}$ \\
\hline 3. Uses multiple assessment strategies. & $\mathrm{X}$ & $\mathrm{X}$ & & $\mathrm{X}$ \\
\hline 4. Provides useful feedback to assist learners in understanding content & $\mathrm{X}$ & $\mathrm{X}$ & $\mathrm{X}$ & $\mathrm{X}$ \\
\hline \multicolumn{5}{|l|}{ knowledge. } \\
\hline 5. Provides opportunities for student self-assessment. & & & & \\
\hline \multicolumn{5}{|l|}{ Technology } \\
\hline 1. Appropriate selection of technology. & & $\mathrm{X}$ & & $\mathrm{X}$ \\
\hline 2. Appropriate use of technology. & & $\mathrm{X}$ & & $\mathrm{X}$ \\
\hline
\end{tabular}




\section{The Equity Principle}

In an equitable mathematics classroom, teachers must have a deep understanding of diversity, mathematical content knowledge, and diagnostic skills to assist students. Further, teachers must also demonstrate those behaviors that promote high-expectations. Two teachers, Betty and Diane did meet proficiency for the Equity Principle and two teachers, Angela and Carol, did not. Betty and Diane each created such a supportive mathematics learning environment that their students appeared to be comfortable interacting with the teacher and with one another. These teachers encouraged student-teacher and student-student communication and positively reinforced students for sharing their thinking and thought processes. This appeared to build a sense of self-worth for the students in these classrooms. Both Betty and Diane demonstrated effective questioning strategies but in different ways. Betty's questioning was posed primarily during whole class instruction whereas Diane posed questions to individuals, small groups, and the whole class. Diane asked questions requiring high levels thinking, and she delved and probed when a student could not answer. For example, Diane asked questions such as "Why can we do this?" "What happens when we do this?" "Can you think of a different way to do this?" These types of questions along with the use of small group and whole class instruction were indicators that Diane appeared to value higher-level thinking, thinking strategies, and differentiated instruction. Furthermore, Diane sparked the students' interest and enthusiasm for learning because she demonstrated those behaviors that communicate high expectations.

Angela and Carol did not demonstrate the descriptors that support the Equity Principle. Neither teacher demonstrated those behaviors and pedagogical practices that communicate high expectations, nor was there evidence of supporting critical discourse among the students. One teacher, Angela, attempted to differentiate instruction although it appeared that little planning and thought went into the process. For example, her instruction appeared to be disorganized; she tried to address the different readiness levels among her students, but was unable to differentiate appropriately. Such disorganization led to confusion and misunderstandings during her instruction. Students who did not easily understand the concept were left alone for an extended period of time, while she tended to the students who were able to grasp the material. When the teacher was able to attend to those students who did not understand the material under study, the other students finished their assignments and began to disrupt the class with talking and other classroom management issues. In addition, Angela tended to ask questions that were shallow and required little elaboration or thinking. Such questioning practices did not allow for much discourse among the students. Sample questions included, "What is the answer to problem three?" 
and "Who knows how to do this problem?" Carol's lessons appeared to be very teacher directed with little input or acknowledgement of her students' needs. Carol primarily used a "one size fits all" model of whole class instruction.

\section{The Curriculum Principle}

Although the participating district utilizes a state mandated curriculum and pacing guide that complemented the mathematics textbook, it is up to the teacher to develop a creative and interesting way to integrate mathematical ideas with real world experiences. All of the teachers demonstrated proficiency of the Curriculum Principle. The teachers followed the state mandated curriculum and used appropriate materials. There was evidence in their lesson plans and overall teaching that they were working towards the intended state standards. All of the teachers appeared to use the pacing guide appropriately. While all the teachers demonstrated proficiency for the Curriculum Principle, Angela and Carol did not infuse creativity within their lesson. That is, these teachers worked towards meeting the standards and objectives of their lesson, but demonstrated little effort towards making the lesson authentic and interconnected. This is evidenced by the teachers demonstrating facts and procedures and not helping students make connections among them. Essentially, the mathematics lessons were taught as isolated facts independent of real world experiences.

\section{The Teaching Principle}

The Teaching Principle requires teachers to have a sophisticated understanding of how children learn mathematics and best practices for teaching mathematics, while maintaining an active, challenging, and nurturing environment (NCTM, 2000). Here, teachers need to address the Process Standards as identified by NCTM (2000) by incorporating problem solving, mathematical reasoning, communicating understandings, connecting mathematical concepts to one another and to the real world, and representing mathematics in multiple ways. The flexible pedagogical style of Diane supported the Teaching Principle. Diane's teaching methodology included high levels of teacher-student and student-student interactions. Students were asked to explain their thinking to one another in pairs and share their thinking in whole class situations. Diane demonstrated multiple representations of mathematics by using hands-on and virtual manipulatives. The manipulatives allowed students to demonstrate their thinking through hands-on manipulation as well as through paper and pencil. This was evidenced by the ways Diane allowed students to use 
drawings and symbols to support their thinking. For example, students had to determine which fraction was greater, $1 / 2$ or $3 / 4$. Students were able to use pattern blocks and drawings to demonstrate and explain their thinking. Such teaching permitted for multiple representations of mathematics, use of different learning modalities, allowed students to see connections beyond a traditional algorithm, and expand students' problem solving repertoire.

Angela, Betty, and Carol had trouble in addressing the Teaching Principle throughout their instruction. Interestingly, none of these teachers were observed using hands-on manipulatives to support their instruction. It appeared that classroom management issues influenced these teachers' instruction. For example, Carol had difficulty managing talkative students in her classroom, and as a result, she had to repeat instructions and procedures. This led to her re-working several problems on an overhead projector and using worksheets to manage behaviors. These pedagogical tactics appeared to be ineffective because many students expressed difficulty in understanding the intended content for several lessons. Students were not encouraged to engage in mathematical discourse, nor were conceptual understandings encouraged. Mathematical representations of the content knowledge were not provided by the teacher. Rote memorization of the procedure was the primary pedagogical strategy Angela utilized. Unfortunately, this style did not meet the needs of most of her students. Angela and Betty also demonstrated similar practices.

\section{The Learning Principle}

Learning mathematics with understanding is directly related to the type of experiences students have with mathematics. There is a close connection between the Teaching Principle and the Learning Principle. The types of experiences that teachers provide for students affect their learning of mathematics. Diane demonstrated proficiency with the Learning Principle. She checked students' understanding through questioning, circumventing erroneous conceptions through use of manipulatives and other representations, and encouraged student participation through discussions and sharing. Diane's use of manipulatives provided focal points for discussions and demonstrations of understandings. Angela, Betty, and Carol did not meet the target for proficiency for the Learning Principle. Unfortunately, because these teachers did not make connections to prior learning and/or experiences, it appeared that students were memorizing concepts, rules, and procedures. However, it appeared that Carol was approaching proficiency for the Teaching and Learning Principles because she only fell short by two indicators for each. 


\section{The Assessment Principle}

The Assessment Principle suggests that teachers use multiple means of assessment and involve students in the assessment process. Varied assessments, such as interviews, journals, and authentic products can provide teachers with important evidence as to the depth of mathematics understanding of students (NCTM, 2000; Sutton \& Krueger, 2002). Diane used feedback from students to alter her instruction and as a means to improve their understanding of the concept presented. In addition, Diane used effective questioning techniques, traditional written assessments, and journals to monitor students' mathematics understanding. Angela, Betty, and Carol fell short of the target for proficiency of the Assessment Principle. Although Angela and Betty did not meet the acceptable benchmark, they evaluated students' work to inform their teaching and gauge their student's understanding. Carol only answered student questions as a means to provide them with feedback, but did not use these questions and responses to adjust her instructional practices. Carol also did not use assessment to monitor student's progress, make instructional decisions, or actively involve them in the assessment process. None of the teachers met proficiency for the descriptor "provides opportunities for student self-assessment." This is a concern because self-assessment helps students build metacognition.

\section{The Technology Principle}

Instructional technology can benefit students in a variety of ways: increased accuracy, speed, interactive modeling of abstract concepts, and data collection and interpretation to name a few (Sutton \& Krueger, 2002). Only two out of the four teachers utilized technology in any of their lessons during these observations. Although the school housed a technology rich library, it appeared that the teachers did not take full advantage of the resources available. Betty and Diane utilized technology differently. Betty allowed students to use calculators to check their work. Diane also utilized calculators, but she encouraged her students to explore different mathematical concepts via the National Library of Virtual Manipulatives. For example, students used virtual manipulatives to explore fraction concepts such as adding and subtracting fractions, comparing fractions, and ordering fractions. Diane used virtual manipulatives to deepen students' understanding and to complement the concrete manipulatives. The researchers observed students using virtual manipulative to move beyond the intended objectives of the lesson to explore other relationships. 


\section{Discussion and Conclusions}

This study focused on how four novice teachers with limited work experience in high poverty schools infused the NCTM Principles within their mathematics pedagogy.

The results suggest that when the NCTM Principles are addressed through the pedagogy and methodology of teachers, students are provided with a more mathematics rich learning environment that allow opportunities for them to examine their mathematical thinking processes, engage in various types of discourse and participate in hands on and authentic activities. The results also highlight the close correspondence between teachers' implementation of Haberman's Acts of Good Teaching $(2005,1991)$ and the NCTM Principles. However, when teachers don't attend to the NCTM Principles, it appears they support a "pedagogy of poverty" as identified by Haberman $(2005,1991)$.

Although the teachers under study varied in the degree to which each of the Principles were addressed in their mathematics instruction, all were judged proficient for the Curriculum Principle. A plausible explanation is that the participating school district provides an intense teacher professional development prior to the beginning of school that focuses on understanding and following the curriculum, the pacing guide, and the depth to which a standard must be taught and mastered by the students. Consequently, if a teacher simply follows expectations, they are aligned with the Curriculum Principle. However, as noted, there were differences in the creativity that characterized the lessons. This suggests that an improved observation instrument may be more sensitive to these variations.

The degree to which each of the teaching indicators categorized according to the remaining five Principles (Equity, Teaching, Learning, Assessment and Technology) were met as well as personal teaching methodologies illuminate specific strengths and weaknesses of the participating teachers. For example, one teacher, Diane, appeared to provide her students with a more enriched mathematics experience than the other teachers by implementing and infusing the Principles. Diane sought ways to maximize her students' mathematical opportunities. She appeared to be pedagogically responsive toward her students and demonstrated many of the best practices advocated by the professional literature and NCTM (2000) such as differentiating instruction, providing real-world problems, and authentic learning opportunities and incorporating multiple representations, problem solving, cooperative group work and manipulatives into her instruction. These strategies are but a few of the instructional practices that are effective in fostering mathematics success among students in urban schools (Boaler, 2006; Balfanz, Mac Iver, \& Byrnes 2006; NCTM, 1999; Smith \& Geller 2004). Additionally, these practices substantiates 
Haberman's model of "Good Teaching” (2005, 1991). In contrast, the other three teachers (Angela, Betty, Carol) were judged to be less proficient in demonstrating these principles in their classrooms. Gimbert, Bol and Wallace (2007) report similar findings, suggesting minimal use of NCTM standards among novice teachers in urban schools. Moreover, current findings appear to indicate that these teachers' pedagogical style can be characterized as "pedagogy of poverty" (Haberman, 2005, 1991). That is, the mathematics experiences provided to the students in these three classroom do little to prepare students for rigorous mathematics that require them to be problem-posers, problem-solvers, and doers of mathematics. Their pedagogical styles were primarily whole class instruction that focused on acquiring facts and procedures; little emphasis was put on conceptual understanding of ideas. However, it appeared that classroom management was a key issue and dictated the mathematics instruction provided. It is plausible to consider that these teachers were so concerned about classroom management that they did not consider using hands-on manipulatives. However, the effective use of hands-on manipulatives can promote positive classroom behaviors.

The findings have immediate implications for teachers of mathematics in urban highpoverty schools. While it is easy to state that these teachers need more professional development and perhaps coursework with mathematics content, mathematics methods, and working with diverse populations, we contend that such activities may have some immediate positive classroom-level effects but may do very little in making long-term change for individual teachers and the professional community of a school. Teacher learning is a catalyst for improvements in teaching and student learning. Improvement in student learning is not as simple as teaching teachers how to teach differently. It requires working in classrooms in such a way that teachers receive continuous support in the process of changing their teaching practices. To support changes in teaching practices with mathematics, it may be necessary to provide elementary teachers with a support mentor who can work with them in their classrooms to assist them with their mathematics instruction. This support mentor should have specialized knowledge of mathematics content, pedagogy, and assessment. Because of their specialized knowledge, the support mentor can serve teachers in several capacities. At times, they can work with teachers to plan mathematics lessons, co-teach mathematics lessons, model good mathematics teaching, serve as a mathematics content resource and help teachers assess students' mathematics learning. The literature describes this school-based mentor as an elementary mathematics specialist (Nickerson \& Moriarity, 2005; Pitt, 2005; Reys \& Fennell, 2003). Elementary mathematics specialists serve as a support for teachers and administrators who want to examine instructional practices within 
their schools so that they can work to improve mathematics teaching and learning (Nickerson \& Moriarity, 2005).

Teachers' professional communities provide the space and environment for learning about teaching practices. In professional communities where teachers are engaged in collaborative inquiry into teaching practices, students experience the kind of learning that the NCTM advocates. Teachers supported by mathematics specialists can develop strong expertise in the teaching and learning of mathematics. Elementary mathematics specialists are first-hand observers and participants in the school culture. These specialists are aware of the needs of the school, provide solutions that address those needs, and help ensure that students within their schools become proficient in mathematics.

The present results illuminate how teachers' pedagogy and practices can support the Principles, or hinder their implementation. The data can serve all teachers in realizing the Principles throughout their mathematics instruction. Additionally, the results make clear that demonstrating some practices that support the Principles are not indicative of the new vision for mathematics teaching as articulated by the NCTM (2000). To create a student centered mathematics learning environment, each of the Principles need to be fully addressed. Gimbert et al. (2007) argued “. . . sporadic use of the instructional practices targeting these process and standards may not advance student learning" (p. 113).

Mathematics teachers must have a clear understanding of the instructional practices that promote the NCTM's Principles and how to implement them effectively with diverse student populations. This understanding will keep teachers to shift from "pedagogy of poverty" to "pedagogy of promise" so that all students can be successful in the learning of mathematics. 


\section{REFERENCES}

Balfanz, R., Mac Iver, D. J., \& Byrnes, V. (2006). The implementation and Impact of Evidence-Based Mathematics Reforms in High-Poverty Middle Schools: A Multi-Site, Multi-Year Study. Journal for Research in Mathematics Education, 37(1), 33-64.

Berry, R. (2003). Mathematics standards, cultural styles, and learning preferences: The plight and the promise of African American students. The Clearing House, 76(5), 244-249.

Boaler, J. (2006). Urban success: A multidimensional mathematics approach with equitable outcomes. Phi Delta Kappan, 87(5), 364-369.

Creswell, J. W. (1998). Qualitative inquiry and research design. Thousand Oaks: Sage Publications.

Darling-Hammond, L. (2000). Solving the dilemmas of teacher supply, demand, and standards: How can we ensure a competent, caring, and qualified teacher for every child. National Commission on Teaching in America's Future. New York: DeWitt Wallace-Reader's Digest Fund.

Gall, M., Borg, W., \& Gall, J. (1996). Educational researcher: An introduction. White Plains, NY: Longman.

Gimbert, B., Bol, L., \& Wallace, D. (2007). The influence of teacher preparation on student achievement and the application of national standards by teachers of mathematics in urban secondary schools. Education and Urban Society, 40(1), 91-117.

Haberman, M. (1991). The pedagogy of poverty versus good teaching. Phi Delta Kappan 75, 290-294.

Haberman, M. (1995). Star teachers of children in poverty. West Lafayette, IN: Kappa Delta Pi.

Haberman, M. (2005). Star teachers: The ideology and best practice of effective teachers of diverse children and youth in poverty. The Haberman Educational Foundation.

Hill, H., Rowan, B., \& Ball, D. (2005). Effects of teachers' mathematical knowledge on student achievement. American Education Research Journal, 42(2), 371-406.

Hill, H., Schilling, S., \& Ball, D. (2004) Developing measures of teachers' mathematics knowledge for teaching. The Elementary School Journal, 105(1), 11-30.

Kilpatrick, J., Swafford, J., \& Findell, B (2001). Adding it up: Helping children learn Mathematics. Washington, DC: National Academy Press.

Lincoln, Y., \& Guba, E. (1985). Naturalistic inquiry. Thousand Oaks, CA: Sage Publications.

Lubienski, S. T. (2001, April). A second look at mathematics achievement gaps: Intersections of race, class, and gender in NAEP data. Paper presented at the American Educational Research Association, Seattle, Wash.

McKinney, S., Bol, L., \& Berube, C. (2008). Mathematics teaching with the stars. Unpublished manuscript, Old Dominion University.

McKinney, S., Berry, R., \& Robinson, J. (2008). Real teaching in the mathematics classroom: A comparison of the instructional practices of teachers in urban high-poverty schools. Unpublished manuscript, Old Dominion University. 
Merlino, F., \& Wolff, E. (2001). Assessing the costs/benefits of an NSF standards-based secondary mathematics curriculum on student achievement. Philadelphia: The Greater Philadelphia Secondary Mathematics Project.

Mewborn, D. (2003). Teaching, teachers' knowledge, and their professional development. In J. Kilpatrick,

W. Martin, \& D. Schifter (Eds.) A research companion to principles and standards for school mathematics. Reston VA: National Council of Teachers of Mathematics.

National Council of Teachers of Mathematics, (1989). Curriculum and evaluation standards for school mathematics. Reston, VA: National Council of Teachers of Mathematics.

National Council of Teachers of Mathematics, (2000). Principles and standards for school mathematics. Edited by NCTM, Reston, VA: National Council of Teachers of Mathematics.

National Council of Teachers of Mathematics (1999). Teaching and learning mathematics in poor communities. Reston,VA: NCTM.

National Library of Virtual Manipulatives. 1999-2006. Retrieved September 1, 2008 from http://nlvm.usu.edu/en/nav/vlibrary.html

Nickerson, S. D., \& Moriarty, G. (2005). Professional communities in the context of teachers' professional lives: A case of mathematics specialists. Journal of Mathematics Teacher Education, 8, 113-140.

Oakes, J. (1990). Opportunities, achievement and choice: Women and minority students in science and mathematics. In C. Cazden (Ed.), Review of research in education, 16 (pp. 153-222). Washington, DC: American Educational Research Association.

Palacios, L. (2005). Critical issue: Mathematics education in the era of NCLB-Principles and standards. Retrieved January 9, 2007 from http://www.ncrel.org/sdrs/areas/issues/content/cntareas/math/ma500.htm

Pitt, L. D. (2005). Mathematics teacher specialists in Virginia: A history. The Journal of Mathematics and Science: Collaborative Explorations, 8, 23-34.

Rampey, B.D., Lutkus, A.D., \& Dion, G. (2006). The nation's report card: Trial urban district assessment mathematics 2005 (NCES 2006-457r). United States Department of Education, National Center for Education Statistics. Washington, D.C: United States Government Printing Office.

Reys, B., \& Fennell, F. (2003). Who should lead mathematics instruction at the elementary school level? A case for mathematics specialists. Teaching Children Mathematics, 9(5), 277-282.

Sanders, W. L., \& Rivers, J. (1996). Cumulative and residual effects of teachers on future student academic achievement. The University of Tennessee Value-Added Research and Assessment Center.

Secada, W. (1992). Race, ethnicity, social class, language achievement in mathematics. In D. Grouws (Ed.), Handbook of research on mathematics teaching and learning (pp. 623-624). New York: Macmillan.

Smith, K. S., \& Geller, C. (2004). Essential principles of effective mathematics instruction: Methods to reach all students. Preventing School Failure, 48(4), 22-29.

Spillane, J., \& Zeuli, J. (1999). Mathematics reforms. Educational Evaluation and Policy Analysis, 21(10, 1-28. 
Stigler, J. W., \& Hiebert, J. (1997). Understanding and improving classroom mathematics instruction. An overview of the TIMSS video study. Phi Delta Kappan, 79(1), 14-21.

Stinson, D. (2006). African American male adolescents, schooling (and mathematics): Deficiency, rejection, and achievement. Review of Educational Research, 76(4), 477-506.

Strutchens, M. E. (2000). Confronting beliefs and stereotypes that impede the mathematical empowerment of African American students. In M. E. Strutchens, M. L. Johnson, and W. F. Tate (Eds.), Changing the faces of mathematics: Perspectives on African Americans (pp 7-14). Reston, VA: National Council of Teachers of Mathematics.

Strutchens, M. E., \& Silver, E. A. (2000). NAEP findings regarding race/ethnicity: Students' performance, school experiences, and attitudes and beliefs. In E. A. Silver \& P. A. Kenney (Eds.), Results from the seventh mathematics assessment of the National Assessment of Educational Progress (pp. 45-72). Reston, VA: NCTM.

Sutton, J., \& Krueger, A. (Eds.) (2002). EDThoughts: What we know about mathematics teaching and learning. Aurora, Colorado: Mid-continent Research for Education and Learning.

Tate, W. F. (1997b). Race ethnicity, SES, gender and language proficiency trends in mathematics achievement: An update. Journal for Research in Mathematics Education, 28(6), 652-679.

Turner, S. (1999). IMP students score higher than their peers on SAT-9. Sausalito, CA: Interactive Mathematics Program.

Wenglinsky, H. (2002). How schools matter: The link between teacher classroom practices and student academic performance. Education Policy Analysis Archives, 10(12). Retrieved January 8, 2007 from $\underline{\text { http://epaa.asu.edu/epaa/v10n12/ }}$

$\begin{array}{ll}\text { Author } & : \text { Sueanne E. McKinney } \\ \text { E-mail } & : \text { sueemac } @ \text { aol.com } \\ \text { Address } & : \text { Old Dominion University, USA }\end{array}$

